ENTREPRENEURSHIP AND SUSTAINABILITY ISSUES

ISSN 2345-0282 (online) http://jssidoi.org/jesi/

2021 Volume 8 Number 3 (March)

http://doi.org/10.9770/jesi.2021.8.3(22)

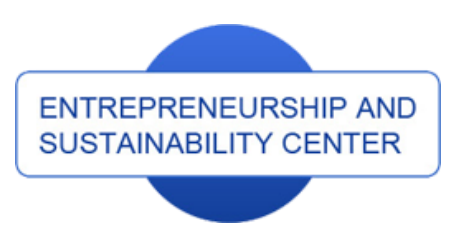

Publisher

$\underline{\text { http://jssidoi.org/esc/home }}$
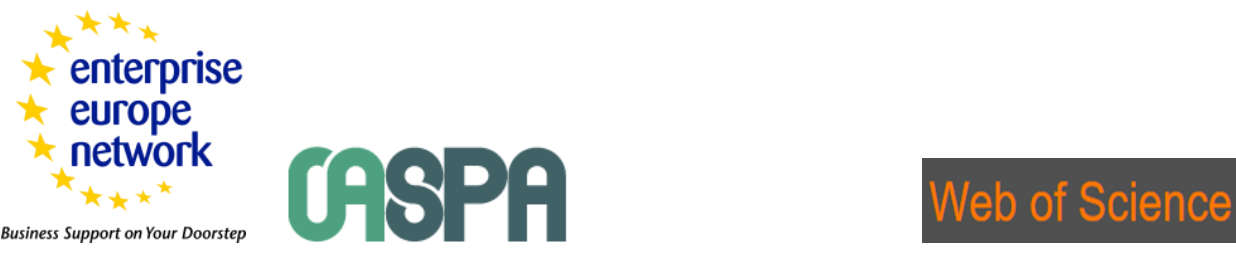

1) Clarivate

Analytics

\title{
LEGAL REGULATION OF ENTREPRENEURIAL ACTIVITY IN THE NATIONAL SECURITY SYSTEM
}

\author{
Olha Bezpalova ${ }^{1 *}$, Maryna Yunina ${ }^{2}$, Svitlana Korohod ${ }^{3}$, Kristina Rezvorovich ${ }^{4}$, Tsahik Ohanisian ${ }^{5}$ \\ 1* Kharkiv National University of Internal Affairs, Lev Landau Avenue, 27, Kharkiv, 61000, Ukraine \\ 2,3,4,5 Dnipropetrovsk State University of Internal Affairs, Ave. Gagarina, 26, 49005, Dnipro, Ukraine \\ E-mail: ${ }^{1 *}$ bezpalova@i.ua (Correponding author)
}

Received 23 March 2020; accepted 10 January 2021; published 30 March 2021

\begin{abstract}
The main directions of the destructive economic impact on business activities in the national security system have been identified, which allowed to identify possible risks for business activities and to develop a set of preventive measures to reduce the negative impact of external factors. Given the current conditions of the macroeconomic situation, it is necessary to constantly monitor the processes that take place in the external environment and have an impact on the state of economic security of business. With the help of international rating indices, which are an important tool, a significant reference point and an external source of information, Ukraine's place in international rankings has been tracked in the second section and a comprehensive assessment has been made, as the relevant rankings places by which world organizations mark Ukraine are indicators of its development. The interrelation and influence of the given indicators on the economic security of entrepreneurial activity are substantiated. According to the study of Ukraine's position in international rankings, it is concluded that Ukraine's position is currently unsatisfactory, Ukraine has not yet created safe conditions for business development: unstable tax legislation, significant corruption pressure and currency restrictions, lack of serious gains in investment attractiveness and to ensure national competitiveness, state support for business development is insufficient and unfocused; limited opportunities for financing state programs for business development. Entrepreneurial activity management in Ukraine is a direction of state policy, a set of measures and forms of economic, legal, and organizational impact on business and entrepreneurs, including through state support and protection of business entities, as well as state control over compliance requirements of the legislation by subjects of such an activity.
\end{abstract}

Keywords: entrepreneurial activity; national security; legal regulation; international rankings; state policy

Reference to this paper should be made as follows: Bezpalova, O., Yunina, M., Korohod, S., Rezvorovich, K., Ohanisian, T. 2021. Legal regulation of entrepreneurial activity in the national security system. Entrepreneurship and Sustainability Issues, 8(3), $340-355$. http://doi.org/10.9770/jesi.2021.8.3(22)

JEL Classifications: F35, F42 


\section{ENTREPRENEURSHIP AND SUSTAINABILITY ISSUES}

ISSN 2345-0282 (online) http://jssidoi.org/jesi/

2021 Volume 8 Number 3 (March)

http://doi.org/10.9770/jesi.2021.8.3(22)

Make your research more visible, join the Twitter account of ENTREPRENEURSHIP AND SUSTAINABILITY ISSUES: @Entrepr69728810

\section{Introduction}

The operation of subjects of entrepreneurial activity takes place in an unstable and chaotic business environment, which is characterized by an increase in the degree of its uncertainty, complexity, and unpredictability (Chehabeddine, M., \& Tvaronavičienė, M. 2020; Mazzanti, M., 2020; Vasconcelos, V.V. 2021). This requires subjects of entrepreneurial activity to respond quickly and adequately to changes in the business environment, to find ways to overcome external threats and to provide the necessary level of economic security. It is economic security that has a determining role in ensuring the sustainable development and competitiveness of subjects of entrepreneurial activity.

With the inclusion of Ukraine's economy in the world economy, in particular, the intensification of European integration processes, there is an objective need to develop a more effective system of economic security of entrepreneurial activity when entering new world markets.

Entrepreneurial activity has always been closely linked to the risks posed by the internal and external environment of businesses. Therefore, ensuring the appropriate level of economic security is an integral prerequisite for entrepreneurial activity in the face of increasing the complexity of business processes, increasing political, economic, social, environmental, and other instability.

The issue of economic security becomes especially relevant and requires the creation of an effective mechanism for managing the system of economic security of entrepreneurial activity. Such a system should be based not only on neutralizing the negative impact of exogenous and endogenous factors on business but also on preventing potential or hidden (latent) threats and eliminating actual dangers, which requires the formation of a set of preventive measures to ensure economic security of entrepreneurial activity.

One of the main tasks to fulfill this is, of course, reforming and improving the entrepreneurial activity management system. After all, the implementation of any changes in the system of entrepreneurship directly depends on how this system will be managed, directed, and controlled. In particular, the current management of business in Ukraine is objectively inefficient and does not meet the requirements of the time.

The purpose of this study is to highlight the basic principles, to reveal key issues, and to prepare specific proposals for improving the legal regulation of administrative entrepreneurial activity management in Ukraine.

\section{Literature Survey}

The problems of economic security of entrepreneurial activity are becoming extremely important, because the factors related to the development of European integration processes, with their impact on the efficiency of entrepreneurial activity, are gaining in importance.

Theoretical principles of economic security of enterprises are reflected in the works of many scientists: McKenny, A. F., et. al. (2017), Fagerberg, J. (2017), Kuhlmann, S., \& Rip, A. (2018) and others.

Peculiarities of the influence of European integration processes on entrepreneurial activity are considered in the works of Flanagan, K., \& Uyarra, E. (2016), Carayannis, EG, Meissner, D., \& Edelkina, A. (2017), Schot, J., \& Steinmueller, WE (2018) and others.

Entrepreneurial activity as one of the most driving forces of economic development of the state requires an 


\section{ENTREPRENEURSHIP AND SUSTAINABILITY ISSUES}

ISSN 2345-0282 (online) http://jssidoi.org/jesi/

2021 Volume 8 Number 3 (March)

http://doi.org/10.9770/jesi.2021.8.3(22)

Make your research more visible, join the Twitter account of ENTREPRENEURSHIP AND SUSTAINABILITY ISSUES: @Entrepr69728810

orderly management process, through which it will acquire clear features of the appropriate activity, will be a way of economic legal employment and a means of ensuring the lives of individuals and the general population. In the modern conditions of state formation in the Ukrainian science of administrative law, there are currently no comprehensive systematic studies on the methodological foundations of business management, so there is a need to study and develop the concept, purpose and objectives, methods, and forms of such management.

It should be noted that the issues of improving the entrepreneurial activity management system in Ukraine have been the subject of active discussions and, accordingly, reflected in the works of scholars on the theory of law, administrative law, commercial (business) law, and other related branches of law, such as: Díez-Martín, F., Blanco-González, A., \& Prado-Román, C. (2016), Kacperczyk, A., \& Younkin, P. (2017), Kibler, E., Salmivaara, V., Stenholm, P., \& Terjesen, S. (2018), Ingram Bogusz, C., Teigland, R., \& Vaast, E. (2019) and others.

The study of theoretical and empirical achievements of these authors makes it possible to say that they have created a theoretical basis and practical tools to ensure the economic security of business have been proposed. At the same time, the deepening of European integration processes, in which Ukraine is involved, forms new requirements for the basic elements of the mechanism of economic security of the entrepreneurial activity management, in particular, the optimization of internal and external information flows. The need to form theoretical foundations and practical tools to ensure the economic security of entrepreneurial activity in the development of European integration processes has led to the choice of topic and direction of research and structure of work.

Without diminishing the importance of scientific developments of these authors, however, it should be noted that in view of the above, today requires a comprehensive study of the problems of business management in Ukraine. It should be emphasized that the issue of entrepreneurial activity management in Ukraine and its improvement have not yet been the subject of a separate study, which, given the ongoing reform of business management and its results (including those strategically planned by 2020), is a significant omission from both theoretical and scientific and practical point of view. Also, the leading practice of business management in economically powerful countries of the world (in particular, the EU and EU member states, the USA, Japan and the PRC) has not been systematically considered in order to make recommendations for the application of such practice in Ukraine. This scientific work is aimed at solving the outlined issues.

\section{Methods}

The methodological basis of the study is a number of general and special methods of cognition, the choice of which is determined by the characteristics of its object, subject, purpose, and objectives.

Thus, the historical method was used to determine the characteristics of entrepreneurial activity in the world and in modern Ukraine, to clarify the essence of entrepreneurial activity as a social and legal phenomenon and its components: the method of classification, induction, and deduction) was used to provide general legal characteristics of management activity concerning entrepreneurship in Ukraine - definition of the purpose, tasks, principles, methods, and forms of management in the specified spheres. The method of systematization in combination with the system-functional method was used during the development of the system of administrative entrepreneurial activity management in Ukraine and the delineation of their powers.

Using the logical-semantic method, the basic concepts in the work are defined. The system-structural method, the method of synthesis, and the method of empirical cognition of observation were used in the study of problems that 


\section{ENTREPRENEURSHIP AND SUSTAINABILITY ISSUES}

ISSN 2345-0282 (online) http://jssidoi.org/jesi/

2021 Volume 8 Number 3 (March)

http://doi.org/10.9770/jesi.2021.8.3(22)

Make your research more visible, join the Twitter account of ENTREPRENEURSHIP AND SUSTAINABILITY ISSUES: @Entrepr69728810

exist in the field of entrepreneurial activity management, which created opportunities to take into account existing practice in this area and theoretical developments of leading scholars of administrative law.

Methods of generalization and classification provided opportunities to develop a general system of international legal level of entrepreneurial activity management. The comparative legal method was used in comparing the norms and provisions of national legislation on the regulation of entrepreneurial activity management in Ukraine and the legislation of developed countries. Formal-dogmatic and modeling method allowed to identify shortcomings in the legal regulation in the research area and to formulate specific proposals for its improvement.

Scientific and theoretical basis for the work includes scientific works of scientists in philosophy, general theory of state and law, administrative, economic, international and European law, other branches of legal sciences, including foreign researchers. Provisions and conclusions are based on the norms of the Constitution of Ukraine, international acts in the field of business regulation, regulations of the Verkhovna Rada of Ukraine, the President of Ukraine, the Cabinet of Ministers of Ukraine, central executive bodies, as well as current legislation of some countries with developed market economies and the EU Member States, the US, Japan, and the PRC).

The information and empirical basis of the study were generalizations of the published practice of national (Chamber of Commerce, National Institute for Strategic Studies and others) and international experts and specialists (GREGO; World Bank, International Finance Corporation, etc).

This approach allowed the author to substantiate its conclusions and suggestions taking into account the needs of the practice, international experience, and the need to improve regulations governing the relationship.

\section{Results}

Entrepreneurial activity management in Ukraine is a direction of state policy, a set of measures and forms of economic, legal, and organizational influence on entrepreneurial activity and entrepreneurs, including through state support and protection of the subjects of entrepreneurial activity, as well as state control over compliance with the law by the subjects of such activities. At the same time, such management is aimed at: ensuring the economic security of the state and the security of society through rational management; achieving effective legal regulation of organizational and economic relations in the state in accordance with the requirements of modernity and the real circumstances of economic reality in the country; achievement of optimally constructed administrative relations between the authorities on the regulation of economic activity; reduction of state intervention in the activities of economic entities and elimination of obstacles to the development of legitimate economic activity.

Today, the development of entrepreneurship in Ukraine has reached a stage where the improvement of the state's regulatory policy determines its further prospects. Consequently, the issues of state regulation of entrepreneurship and the means of influence of the state (public administration systems in general) on entrepreneurial activity are significantly relevant. Secondly, it should be emphasized that the formation of a comprehensive system of means of state regulation of entrepreneurship has not yet been completed in Ukraine. In this regard, we can see the chaotic, inconsistent, and fragmentary actions of public authorities in the development and implementation of modern public policy in the field of entrepreneurship, which would meet the standards and conditions of a market economy.

It should be noted that the system of bodies carrying out general administrative entrepreneurial activity management in Ukraine is multifaceted, as such a system includes all state authorities, which are authorized to 


\section{ENTREPRENEURSHIP AND SUSTAINABILITY ISSUES}

ISSN 2345-0282 (online) http://jssidoi.org/jesi/

2021 Volume 8 Number 3 (March)

http://doi.org/10.9770/jesi.2021.8.3(22)

Make your research more visible, join the Twitter account of ENTREPRENEURSHIP AND SUSTAINABILITY ISSUES: @Entrepr69728810

protect national security. However, the most important part of the study is the analysis of the relevant rights and responsibilities of bodies carrying out special administrative entrepreneurial activity management in the field of economic security (On approval of the Procedure for state accreditation of institutions conducting training, retraining and advanced training of drivers of vehicles, and certification of their specialists (2009), as well as the safety and well-being of the population, so let's move on to the second group of bodies, namely the system of bodies that carry out special administrative entrepreneurial activity management in Ukraine.

For example, according to the Law of Ukraine "On the Foundations of National Security of Ukraine" (2003), the concept of "economic security" is part of a broader concept - "national security of Ukraine", which is carried out by conducting a balanced public policy in accordance with duly adopted doctrines, concepts, strategies, and programs in the political, economic, social, military, environmental, scientific and technological, information, and other areas.

Entrepreneurial activity plays an important role in a significant part of the economic security of the state: both as a factor in ensuring and growing the economy, and as a factor in stopping such economic growth and "destroying" the state's economy as a whole. This is due to the fact that the activities of entrepreneurs in the Ukrainian market affect the state of growth or decline in prices, as well as in the field of competition, taxes and fees, etc. Therefore, given that the economic security of Ukraine, as a state with a market economy that is significantly globalized, directly depends on security and ensuring the security in the field of competition and taxes and fees, in the field of state customs, pricing and commodity prices, services, etc, the availability and efficient and optimal operation of bodies carrying out special administrative entrepreneurial activity management in the field of economic security are difficult to underestimate.

At the same time, a special administrative entrepreneurial activity management in the field of economic security is carried out by a number of central public authorities and their subordinate authorities within their own powers. However, given the various sectors and subsectors of the economy and state economic policy of our state and the relevant bodies, which are responsible for security in the relevant sectors and subsectors of the economy, it is most appropriate to consider these bodies given the specific subject of their commitment.

Economic security in the field of economic competition is provided in our country by the Antimonopoly Committee of Ukraine (hereinafter - AMCU), which is a state body under the control of the President of Ukraine (accountable to the Verkhovna Rada), a body with a special status, the purpose of which, respectively, is to ensure state protection of competition in entrepreneurial activity and in the field of public procurement.

It is difficult to underestimate the impact of the development of new and improvement of existing regulations, in particular the impact of bringing Ukrainian tax and customs legislation in line with the acquis Communautaire on the state and development of entrepreneurial activity in the country. In particular, the current tax legislation can be described as contradictory, uncertain, unstable, and inadequate to current business conditions; for the functioning of tax policy, it is necessary to reorient it from purely fiscal goals to stimulate economic growth. At the same time, the introduction of new tax legislation has led to mass closures of enterprises compared to previous years.

The significant number and frequency of changes and additions to the regulations of tax legislation significantly complicate the work of regulatory authorities and negatively affects the activities of business entities, as well as reduces the attractiveness of the national economy for foreign investors. 


\section{ENTREPRENEURSHIP AND SUSTAINABILITY ISSUES}

ISSN 2345-0282 (online) http://jssidoi.org/jesi/

2021 Volume 8 Number 3 (March)

http://doi.org/10.9770/jesi.2021.8.3(22)

Make your research more visible, join the Twitter account of ENTREPRENEURSHIP AND SUSTAINABILITY ISSUES: @Entrepr69728810

It follows that entrepreneurial activity can directly affect the safety and well-being of the population concerned, especially when in the course of their economic activity entrepreneurs carry out: transportation, storage and use (exploitation) of non-food products; production, storage, transportation, use, burial, destruction and utilization of toxic substances; construction, dredging works; extraction of sand and gravel; laying of cables, pipelines, and other communications on the lands of the water fund; production, storage, transportation, sale, disposal, and destruction of medicines; storage, transportation, trade and use of plant protection products and the use of pesticides and agrochemicals.

So, in conclusion, we consider it appropriate to emphasize that the system of bodies that carry out special administrative entrepreneurial activity management is multifaceted, given the diversity of national security areas that can be harmed by entrepreneurial activity. Thus, the bodies carrying out special administrative entrepreneurial activity management in the field of economic security of Ukraine include: the Antimonopoly Committee of Ukraine, the State Fiscal Service of Ukraine, the National Commission for Economic Security in Financial Services Markets, the National Securities and Stock Market Commission. In turn, the bodies carrying out special administrative entrepreneurial activity management in the field of safety and well-being of the population in Ukraine include: Sanitary and Epidemiological Service, State Ecological Inspectorate, State Service for Medicines and Drug Control, and State Inspectorate for Human Rights consumers.

Ukraine is actively integrating into the European economic space, and therefore the definition and analysis of positions in key international indices is an important task to ensure the economic security of entrepreneurial activity in the context of European integration. International rankings are an important source of information that outlines the various aspects of economic processes in countries. The analysis of the country's place is especially important for making managerial decisions to ensure economic security. Rating indices are an important tool, an important reference point and an external source of information in the development of preventive measures.

Analysis of objective data that reflects the current state of Ukraine's economy is a necessary element of the study, which allows to identify existing trends and becomes the basis of research hypotheses. As part of the task of analyzing the objective preconditions for the transformation of latent threats into existing ones for entrepreneurial activity in the context of the development of European integration processes, the state and dynamics of the external environment should be analyzed in the context of economic security. At the same time, within the study, the authors are interested in the dynamics of indicators that reflect some of the target guidelines for the transformation of the economic system at different levels.

Given the current conditions of the macroeconomic situation, it is necessary to constantly monitor Ukraine's place in international rankings and make a comprehensive assessment, as the relevant rankings, which mark Ukraine's world organizations, are indicators of its development.

One of the main rating systems that allows to determine the level of economic security and the level of integration of Ukraine into the European community is the Global Competitiveness Index (GCI), which is determined by the World Economic Forum. Global competitiveness is assessed by the following parameters: the situation of institutions, infrastructure efficiency, macroeconomic stability, health and primary education, higher education and training, market efficiency of goods and services, labor market efficiency, financial market development, technological level, competitiveness of companies, market size and innovation potential (Global Peace Index). Therefore, we consider it appropriate in the context of this study to analyze the rating positions of Ukraine on this index (Figure 1). 
ENTREPRENEURSHIP AND SUSTAINABILITY ISSUES

ISSN 2345-0282 (online) http://jssidoi.org/jesi/

2021 Volume 8 Number 3 (March)

http://doi.org/10.9770/jesi.2021.8.3(22)

Make your research more visible, join the Twitter account of ENTREPRENEURSHIP AND SUSTAINABILITY ISSUES: @Entrepr69728810

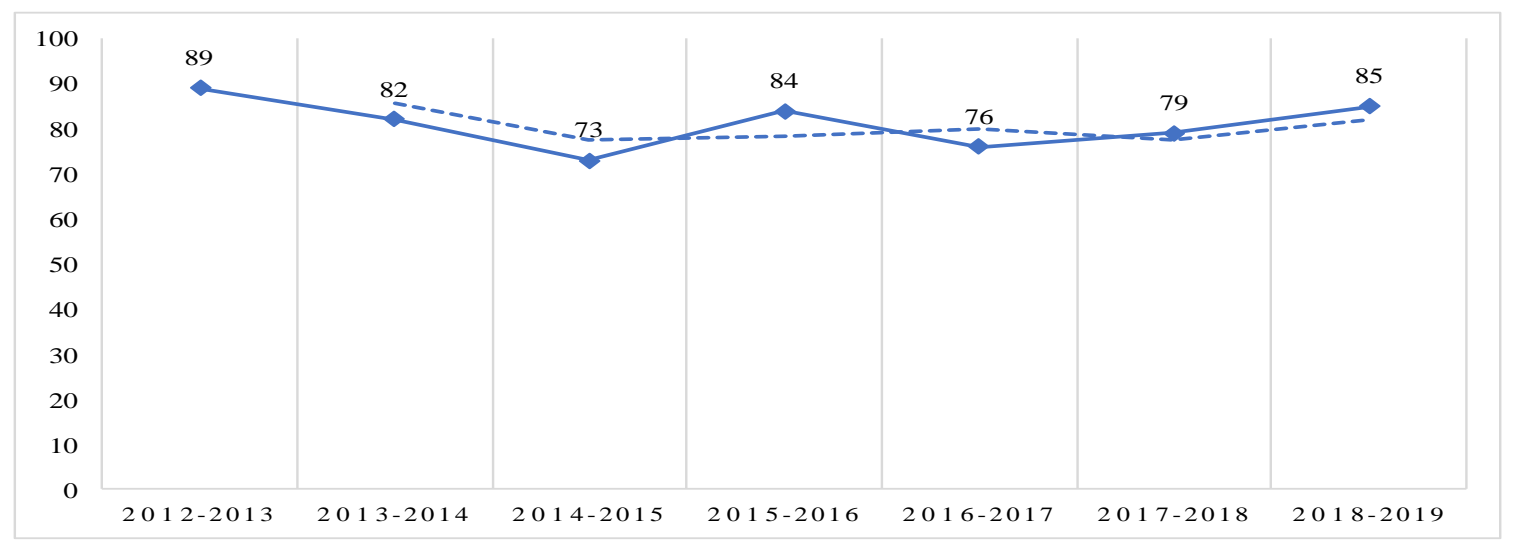

Figure 1. Dynamics of changes in Ukraine's position in the ranking of the Global Competitiveness Index for 2012-2018

Source: built by the author on the basis of Global Peace Index

The analysis of Ukraine's rating positions in the dynamics for 2012-2018 according to the Global Competitiveness Index showed a wave-like dynamics with a significant lag behind highly developed European countries. The dynamics of the global competitiveness index has shown that Ukraine's position fluctuates due to crisis situations.

The indicators that affect the development and state of economic security entrepreneurial activity in Ukraine are considered. According to the indicators such as infrastructure, Ukraine ranks $75^{\text {th }}$, macroeconomic environment $128^{\text {th }}$, business compliance with modern requirements $-98^{\text {th }}$, level of innovation -52 th, efficiency of the goods market $-108^{\text {th }}$, labor market efficiency -73 th, financial market development $-130^{\text {th }}$, technology development 81th (Global Peace Index). The main purpose of the rating should be to determine the indicators of future development of the national economy and the openness of the national market to external participants. The dynamics of Ukraine's position in this ranking is still disappointing.

With the help of this index, ten components grouped into four categories are analyzed. The index of economic freedom is measured as a percentage in the range from 0 to 100. The lower the value, the lower the degree of economic freedom, respectively, the maximum value corresponds to the highest degree of economic freedom. All countries participating in the analysis of this index are divided into the following groups (Index of Economic Freedom): free - with an index of 80-100; mostly free - with an index of 70-79.9; moderately free - with an index of 60-69.9; mostly unfree - with a rate of 50-59.9; despotic - with an index of 0-49.9. The correspondence of the dynamics of growth of economic freedom characterizes the higher level of economic security.

The state and dynamics of this indicator by categories are analyzed, the results of the analysis are presented in Table 1. 
Make your research more visible, join the Twitter account of ENTREPRENEURSHIP AND SUSTAINABILITY ISSUES: @Entrepr69728810

Table 1. Dynamics of the index of economic freedom of Ukraine

\begin{tabular}{|l|l|l|c|}
\hline \multicolumn{1}{|c|}{ Name of the category } & $\mathbf{2 0 1 6}$ & $\mathbf{2 0 1 8}$ & Increase +/- \\
\hline Government spending & 29,4 & 38,2 & $+8,8$ \\
\hline Monetary freedom & 67,7 & 47,4 & $+20,3$ \\
\hline Property rights & 30,0 & 41,4 & $+11,4$ \\
\hline Freedom of business & 46,2 & 62,1 & $+15,9$ \\
\hline Freedom from corruption & 24,0 & 29,2 & $+5,2$ \\
\hline Freedom of investment & 20,0 & 25,0 & $+5,0$ \\
\hline Freedom of the labor market & 51,2 & 48,8 & $+2,4$ \\
\hline Freedom of trade & 84,4 & 85,9 & $+1,5$ \\
\hline Financial freedom & 30,0 & 30,0 & 0 \\
\hline Fiscal freedom & 78,2 & 78,6 & $+0,4$ \\
\hline General index of economic freedom & 46,1 & 48,1 & +2 \\
\hline
\end{tabular}

Source: built by the author on the basis Index of Economic Freedom

Dynamics of changes in the general index of economic freedom of Ukraine in the rating for 2010-2017 is visualized in Figure 2.

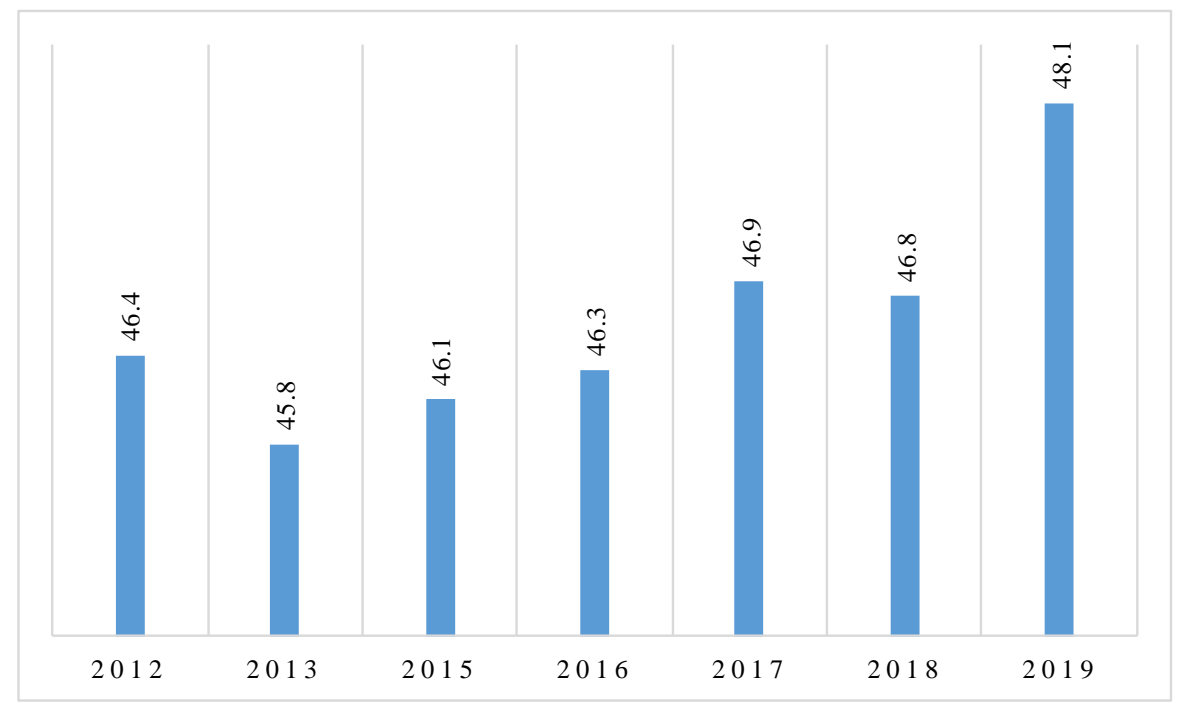

Figure 2. Dynamics of changes in Ukraine's position in the ranking of the Index of Economic Freedom for 2012-2018 Source: built by the author on the basis Index of Economic Freedom

In order to identify the relationship between the level of economic freedom in the state and the economic security of entrepreneurial activity, it is necessary to consider the impact of individual components of economic freedom on the functional areas of economic security. Components that are part of the rule of law (protection of property rights, freedom from corruption) are part of the socio-political factors that contribute to ensuring an appropriate level of judicial or legal security. Regulatory efficiency is the third group, which includes: freedom of business, 
ENTREPRENEURSHIP AND SUSTAINABILITY ISSUES

ISSN 2345-0282 (online) http://jssidoi.org/jesi/

2021 Volume 8 Number 3 (March)

http://doi.org/10.9770/jesi.2021.8.3(22)

Make your research more visible, join the Twitter account of ENTREPRENEURSHIP AND SUSTAINABILITY ISSUES: @Entrepr69728810

freedom of the labor market, monetary freedom. This group has the greatest impact on the state of the intellectual and personnel component of economic security. The last group is the openness of markets, which consists of freedom of trade, freedom of investment, and financial freedom.

It should be noted that freedom of trade is the only component that has a high position in Ukraine but freedom of investment and financial freedom are at a critical level, which has an extremely negative impact on the investment and financial components of economic security. Freedom of entrepreneurship is a prerequisite for the economic security of entrepreneurial activity in the context of the development of European integration processes. However, according to 2019, Ukraine ranked the lowest among European countries in the ranking of economic freedom.

In the process of assessing the economic security of entrepreneurial activity, it is advisable to use methods of assessing the favorable business environment based on the results of the rating "Doing Business", which is calculated annually by the International Finance Corporation (IFC). The Doing Business Index is an index of comparison of ease of carrying out entrepreneurial activity between countries around the world, which is measured by ten points that affect its formation (Figure 3 ).

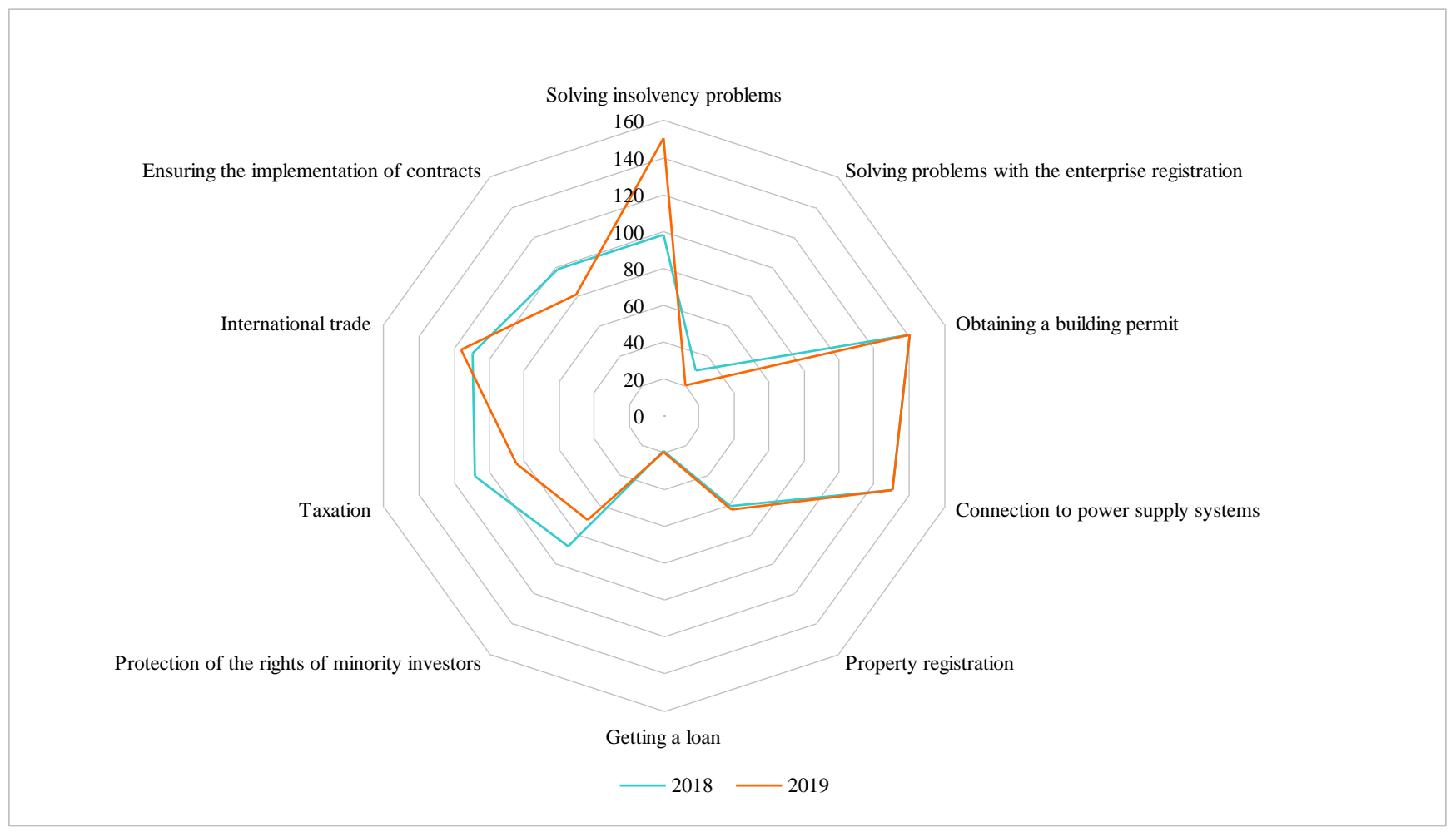

Figure 3. Change in the Ukraine's position under the main components of the rating of ease of doing business for 2018-2019 Source: built by the author on the basis Doing business

Within the World Bank's Doing Business rating, the regulatory conditions are analyzed, which apply to economic entities in the country throughout their life cycle, namely, starting from the establishment of an enterprise and directly conducting business, engaging in foreign economic activity, which acquires a special significance in the conditions of development of European integration processes. The higher the country's position in the World 
ENTREPRENEURSHIP AND SUSTAINABILITY ISSUES

ISSN 2345-0282 (online) http://jssidoi.org/jesi/

2021 Volume 8 Number 3 (March)

http://doi.org/10.9770/jesi.2021.8.3(22)

Make your research more visible, join the Twitter account of ENTREPRENEURSHIP AND SUSTAINABILITY ISSUES: @Entrepr69728810

Bank's Doing Business rating, the more favorable the conditions for the organization of entrepreneurial activity, its functioning, and the state of economic security.

Given the results of the Doing Business rating for 2018-2019, which shows the ease of doing business in the country, we can conclude that Ukraine's business climate is very low and the government does not create the necessary favorable conditions to improve the situation in this sector of the economy, namely, registration of enterprises, registration of property, obtaining loans, protection of minority investors, taxation, international trade, and insolvency.

The results of the analysis showed Ukraine's low position, which is due to the real economic situation in the country, a set of exogenous factors, including: instability and imperfection of the regulatory framework, irrational taxation system, high level of corruption in government and judiciary, inappropriate monetary policy, high level shadow economy, low level of protection of property rights, solvency of the population, political instability, high inflation, trade barriers, non-transparency of business conditions, etc.

For a more compact and clear presentation of information in digital form, Table 2 summarizes the main indicators of Ukraine's position in world rankings in the dynamics for 2014-2019, which may indicate the level of economic development, the degree of doing business, the main obstacles to business development, opportunities and the potential of the country, etc.

Table 2. Ukraine's place in world rankings in the dynamics for 2014-2019

\begin{tabular}{|c|c|c|c|c|}
\hline \multirow[b]{2}{*}{ Indexes } & \multicolumn{2}{|c|}{ Years } & \multirow{2}{*}{$\begin{array}{c}\text { Number of countries } \\
\text { participating in the ranking }\end{array}$} & \multirow[b]{2}{*}{ Deviation } \\
\hline & $\begin{array}{l}2014- \\
2015\end{array}$ & $\begin{array}{l}2018- \\
2019\end{array}$ & & \\
\hline Global Competitiveness Index & 73 & 85 & $144-138$ & -12 \\
\hline The IMD World Competitiveness & 50 & 59 & $60-61$ & -9 \\
\hline Doing Business & 86 & 83 & $132-138$ & +3 \\
\hline The Enabling Trade Index & 64 & 61 & 136 & +3 \\
\hline The level of the shadow economy & 34 & 32 & 28 & -2 \\
\hline Index of economic freedom & 163 & 162 & $179-178$ & +1 \\
\hline BDO Intemational Business Compass & 115 & 130 & 174 & -15 \\
\hline
\end{tabular}

Source: systematized by the author

Diagnosis of economic security of entrepreneurial activity in the development of European integration processes, unfavorable socio-political and economic situation in the country is an important step in identifying hazards that may harm the level of economic security and making appropriate management decisions to ensure it. In order to develop preventive measures, it is important to analyze the current state in which the subjects of entrepreneurial activity operate. Thus, there is a need to diagnose the state of economic security entrepreneurial activity in the dynamics to identify latent risks, positive and negative changes under the influence of threats of exogenous and endogenous factors.

Given the diverse set of exogenous factors that affect the activities of economic entities, the diagnosis of economic security should begin with an analysis of the main indicators of the financial component of economic security. 


\section{ENTREPRENEURSHIP AND SUSTAINABILITY ISSUES}

ISSN 2345-0282 (online) http://jssidoi.org/jesi/

2021 Volume 8 Number 3 (March)

http://doi.org/10.9770/jesi.2021.8.3(22)

Make your research more visible, join the Twitter account of ENTREPRENEURSHIP AND SUSTAINABILITY ISSUES: @Entrepr69728810

In the absence of profit or loss, it cannot be said that the subject of entrepreneurial activity is in economic security. To ensure economic security of entrepreneurial activity in the conditions of constant intensification of competition, it is necessary to reliably assess and monitor the dynamics of the financial condition.

The shadowing of the economy is one of the main threats to both the economic security of the state and the economic security of entrepreneurial activity. The shadow economy is one of the important destabilizing external factors that affect the state of economic security entrepreneurial activity. The shadow economy is an unregistered economic activity of an economic entity, which is characterized by minimization of costs for the production of goods, works and services, tax evasion, fees (mandatory payments), statistical questionnaires and statistical reporting, the result of which is a violation of statutory norms (the level of the minimum wage, working hours, working conditions and safety, etc).

In developed countries, the optimal structure of the economy is achieved through a rational combination of large, medium, and small enterprises. The patterns of the scientific and technological revolution and the problem of employment of the population reinforce the economic necessity of coexistence and interaction of enterprises of different sizes. The Western economy relies on large companies that provide it with stability and manageability, as well as small and medium enterprises, which form a competitive environment that provides flexibility and dynamism of the economy, individualization of production and services, high employment. Moreover, a significant proportion of small and medium-sized enterprises exist with and for large companies, and the sustainability of the situation, income, financial and investment opportunities of small firms directly depend on their relationship with big business.

The experience of development of Western countries shows that the successful functioning of the market mechanism requires an appropriate system of property rights, laws and regulations that ensure their transfer, legal institutions, and decision-making mechanisms. Excessive government intervention leads to deformation of market processes and falling production efficiency. However, deregulation without economic order, the formation of effective socio-economic mechanisms, and strict control can turn into economic anarchy. A well-balanced policy is needed on this issue.

The above-mentioned business management practice in the EU, USA and Japan and PRC indicates the need to regulate a special set of business management tools in the country. The concept of business management in these countries is based on the objective idea that entrepreneurial activity is the foundation and guarantor of the state economy, so management based on state support for entrepreneurship means supporting the economy of the state itself. However, state aid to entrepreneurship alone is not considered to be a full-fledged business management.

An important stage in the evolution of business management in Ukraine should be the deregulation of business following the example of developed countries such as the USA and Japan. At the same time, given the fact that Ukraine pursues the ambitious goal of EU membership, such deregulation should not contradict EU law, to which Ukrainian legislation is approaching in the process of adaptation.

\section{Discussion}

Today in Ukraine there is a wide process of business deregulation through the adoption of relevant deregulatory regulations. At the same time, experts note that despite the government's declaration of reforms to stimulate business, entrepreneurs are still forced to work under excessive state pressure. Parliament passes laws aimed at deregulating business but, in practice, these rules either do not change the situation fundamentally or are simply 


\section{ENTREPRENEURSHIP AND SUSTAINABILITY ISSUES}

ISSN 2345-0282 (online) http://jssidoi.org/jesi/

2021 Volume 8 Number 3 (March)

http://doi.org/10.9770/jesi.2021.8.3(22)

Make your research more visible, join the Twitter account of ENTREPRENEURSHIP AND SUSTAINABILITY ISSUES: @Entrepr69728810

sabotaged by officials. It is necessary to agree with such position as the deregulation which occurs in our state is not always such as it is registered in the corresponding regulations.

Thus, we believe that enterprises in Ukraine need more freedom, and such freedom should really be the ability of enterprises to act in accordance with their economic interests and goals, based on the knowledge of objective business needs. However, of course, such freedom should not be arbitrary and violate legitimate public and state interests. To balance entrepreneurial freedom and the interests of society and the state, it must be regulated and put into practice.

Legal economic order. According to Art. 5 of the Commercial Code of Ukraine (CC of Ukraine), such an order in Ukraine is formed on the basis of optimal combination of market self-regulation of economic relations and economic regulation of macroeconomic processes, based on the constitutional requirement of state responsibility for its activities and definition of Ukraine as a sovereign and independent, democratic, social, and legal state.

It should also be noted that we have already emphasized above the fact that in Ukraine an excessive number of authorized bodies are involved in the entrepreneurial activity management. Therefore, given that the system of bodies engaged in special administrative entrepreneurial activity management in Ukraine is characterized as overloaded with a significant number of bodies (this, of course, negatively affects the investment climate of our country, the attractiveness of doing business for citizens and residents, as well as causes an increase in corruption), the authors propose to take as a model the US system (there is the principle of the market, in which a number of issues are not controlled by entrepreneurs but by the customers of this entrepreneur; the number of special bodies is minimized) or Japan (as in the United States - there are regulatory authorities but in fact there are several authorities - antitrust, fiscal, securities and stock market authorities, a special authority).

Based on this, the authors consider it appropriate to create a special body (or reorganize, provide the following functions of the State Regulatory Service of Ukraine) and eliminate (with the subsequent transfer of powers of such bodies to the special) the following authorities: National Commission for State Regulation of Financial Services Markets; State Sanitary and Epidemiological Service of Ukraine; State Ecological Inspectorate of Ukraine; State Service of Ukraine for Medicines and Drug Control; State Veterinary and Phytosanitary Service of Ukraine; State Inspectorate of Ukraine for Consumer Protection. The functions performed by these bodies (based on the experience of economically developed countries that have achieved economic success, in part by fighting bureaucracy) may be performed by one body, to which inspectors on all these special issues will be recruited on the basis of a public competition on the principle: 2 inspectors on the indicated issues work in the district and the city (also in the city districts); 8 inspectors - in the region; 1 chief inspector and two deputies - work at the central level.

Thus, the authors conclude that the legal economic order in our country is sufficiently regulated but it should be provided with more liberalized instruments and those that will best meet global trends in entrepreneurial activity management. To do this, our state should borrow the experience of the United States and Japan and introduce their models to encourage entrepreneurship. The American model is based on a system of comprehensive encouragement of entrepreneurship, which contributes to the enrichment of the most active part of the population.

An acceptable standard of living for low-income groups and the regulation of other economic issues are ensured through the redistribution of part of national income and tax functions. The Japanese model is characterized by the leading influence of the state on the main directions of economic development. Various production 
ENTREPRENEURSHIP AND SUSTAINABILITY ISSUES

ISSN 2345-0282 (online) http://jssidoi.org/jesi/

2021 Volume 8 Number 3 (March)

http://doi.org/10.9770/jesi.2021.8.3(22)

Make your research more visible, join the Twitter account of ENTREPRENEURSHIP AND SUSTAINABILITY ISSUES: @Entrepr69728810

corporations and associations take on the solution of social problems. At the same time, the participation of employees in production management is encouraged.

At the same time, to adopt the experience of Japan, the state authorities of Ukraine should:

a) create conditions for providing easily accessible financial funds for starting a small business;

b) review the system of small business taxation (in general, the main areas of state support that allow to realize the potential effect of business development include: the formation of a favorable business climate; removal of legal, administrative, and organizational barriers; expanding access to small and medium enterprises to financial resources, development of leasing of equipment and technologies, systematic development of infrastructure for providing small and medium enterprises with integrated financial, material, informational, consulting, and organizational and methodological assistance);

c) to strengthen the connection between the creation of small and medium enterprises with academic knowledge, higher education institutions through the establishment of academic incubators and pre-incubators.

d) provide the possibility of continuing education for entrepreneurs (consultations, seminars, trainings, second education, training courses and retraining).

In addition, we consider it necessary to develop and adopt a legislative act entitled "Fundamentals of entrepreneurial activity management in Ukraine" in the process of formation of modern administrative and legal regulation of entrepreneurial activity management in Ukraine.

Within the framework of such a normative legal act, a set of general rules and standards of entrepreneurial activity management in our state should be regulated, namely: concepts and objects, subjects (their powers) of the entrepreneurial activity management; basic legal, economic, social, environmental, humanitarian and organizational and legal principles of entrepreneurial activity management in Ukraine; control over the performance of functions of entrepreneurial activity management; liability for violation of legislation on entrepreneurial activity management.

It should also be noted that the regulations on entrepreneurial activity in Ukraine are characterized by the gradual democratization of the regulation of such activities, which is caused, first of all, by the deeper integration of our country into the European Union. However, despite the fact that certain norms of Ukrainian legislation are even more flexible than similar ones in the EU member states, due to many objective and subjective factors, the legal norms on entrepreneurship in Ukraine cannot yet correspond to European ones in terms of perfection and efficiency.

The imperfection of the Ukrainian legislation regulating entrepreneurial activity is deepened by a number of factors: first, the lack of legally defined concepts of "economic capacity", "economic capacity", "economic legal personality"; secondly, the unregulated economic commercial activity of a private enterprise and the very nature of such an enterprise; thirdly, the lack of normative regulation of entrepreneurial activity of persons belonging to "free professions", which indicates the need to develop and adopt a law of Ukraine "On free professions", which would regulate, inter alia, the issues of legal status and economic legal personality of individuals that belong to the category of "free professions"; fourth, limited forms of investment in the Ukrainian economy. 
ENTREPRENEURSHIP AND SUSTAINABILITY ISSUES

ISSN 2345-0282 (online) http://jssidoi.org/jesi/

2021 Volume 8 Number 3 (March)

http://doi.org/10.9770/jesi.2021.8.3(22)

Make your research more visible, join the Twitter account of ENTREPRENEURSHIP AND SUSTAINABILITY ISSUES: @Entrepr69728810

\section{Conclusions}

Based on the research, it can be concluded that the rapid development of entrepreneurial activity in Ukraine, increasing business risks and reducing the security of entrepreneurial activity related to Ukraine's European integration processes requires the formation of scientifically sound approaches to early prevention of latent threats and timely response to identified dangers of entrepreneurial activity in the context of European integration. The state and prospects of development and conditions of entrepreneurial activity in Ukraine in terms of European integration are analyzed in the paper based on a study of Ukraine's position in international rankings and world statistics, which are compiled by international organizations and institutions and reveal various aspects of economic processes in the country.

According to the analysis of Ukraine's place in international rankings, it is determined that Ukraine's position is currently unsatisfactory, and the conditions for entrepreneurial activity in Ukraine are extremely dangerous: unstable tax legislation, significant corruption pressure and currency restrictions, lack of significant achievements in ensuring investment attractiveness and ensuring the national competitiveness, the state support for the development of entrepreneurial activity is insufficient and unfocused; limited opportunities to finance state programs for entrepreneurial activity development.

In conclusion, the practice of business management in the EU, the USA, Japan, and the PRC indicates the need to regulate a special set of business management tools in Ukraine. Following the example of these states, the concept of business management should be developed and implemented in Ukraine, which is based on the objective truth that entrepreneurial activity is the foundation and guarantor of the state economy, so management based on state support of entrepreneurship means supporting the state's economy.

In addition, it is objectively appropriate to develop and adopt a new version of the Law of Ukraine "On Development and State Support of Small and Medium Enterprises in Ukraine" in the form of the Law "On Encouragement of Small and Medium Enterprises in Ukraine". In order to standardize and achieve fair entrepreneurial activity management in Ukraine, it is recommended to develop and create a special legislative act "Principles of entrepreneurial activity management in Ukraine".

\section{References}

Carayannis, E. G., Meissner, D., \& Edelkina, A. (2017). Targeted innovation policy and practice intelligence (TIP2E): concepts and implications for theory, policy and practice. The Journal of Technology Transfer, 42(3), 460-484. Available at: https://link.springer.com/article/10.1007/s10961-015-9433-8

Chehabeddine, M., \& Tvaronavičienè, M. (2020). Securing regional development. Insights into Regional Development, 2(1), 430-442. http://doi.org/10.9770/IRD.2020.2.1(3)

Díez-Martín, F., Blanco-González, A., \& Prado-Román, C. (2016). Explaining nation-wide differences in entrepreneurial activity: A legitimacy perspective. International Entrepreneurship and Management Journal, 12(4), 1079-1102. Available at: https://link.springer.com/article/10.1007/s11365-015-0381-4

Doing business. Available at: http://www.doingbusiness.org/data/exploreeconomies/ukraine 


\section{ENTREPRENEURSHIP AND SUSTAINABILITY ISSUES}

ISSN 2345-0282 (online) http://jssidoi.org/jesi/

2021 Volume 8 Number 3 (March)

http://doi.org/10.9770/jesi.2021.8.3(22)

Make your research more visible, join the Twitter account of ENTREPRENEURSHIP AND SUSTAINABILITY ISSUES: @Entrepr69728810

Fagerberg, J. (2017). Innovation policy: Rationales, lessons and challenges. Journal of Economic Surveys, 31(2), 497-512. Available at: https://onlinelibrary.wiley.com/doi/abs/10.1111/joes.12164

Flanagan, K., \& Uyarra, E. (2016). Four dangers in innovation policy studies-and how to avoid them. Industry and Innovation, 23(2), 177188. Available at: https://www.tandfonline.com/doi/abs/10.1080/13662716.2016.1146126

Global Peace Index. Available at: http://visionofhumanity.org

Index of Economic Freedom. Available at: http://www.heritage.org/index/ranking

Ingram Bogusz, C., Teigland, R., \& Vaast, E. (2019). Designed entrepreneurial legitimacy: the case of a Swedish crowdfunding platform. $\begin{array}{llllll}\text { European Journal of } \text { Information } & \text { Systems, }\end{array}$ https://orsociety.tandfonline.com/doi/full/10.1080/0960085X.2018.1534039

Kacperczyk, A., \& Younkin, P. (2017). The paradox of breadth: The tension between experience and legitimacy in the transition to entrepreneurship. Administrative Science Quarterly, 62(4), 731-764. Available https://journals.sagepub.com/doi/abs/10.1177/0001839217700352

Kibler, E., Salmivaara, V., Stenholm, P., \& Terjesen, S. (2018). The evaluative legitimacy of social entrepreneurship in capitalist welfare systems. Journal of World Business, 53(6), 944-957. https://doi.org/10.1016/j.jwb.2018.08.002

Kuhlmann, S., \& Rip, A. (2018). Next-generation innovation policy and grand challenges. Science and public policy, 45(4), 448-454. Available at: https://academic.oup.com/spp/article-abstract/45/4/448/4915392

Mazzanti, M., Mazzarano, M., Pronti, A., \& Quatrosi, M. (2020). Fiscal policies, public investments and wellbeing: mapping the evolution of the EU. Insights into Regional Development, 2(4), 725-749. http://doi.org/10.9770/IRD.2020.2.4(1)

McKenny, A. F., Allison, T. H., Ketchen Jr, D. J., Short, J. C., \& Ireland, R. D. (2017). How should crowdfunding research evolve? A survey of the entrepreneurship theory and practice editorial board. Entrepreneurship Theory and Practice, 41(2), 291-304. Available at: https://journals.sagepub.com/doi/abs/10.1111/etap.12269

On approval of the Procedure for state accreditation of institutions conducting training, retraining and advanced training of drivers of vehicles, and certification of their specialists (2009). Available at: https://zakon.rada.gov.ua/laws/show/490-2009-ח\#Text

On the foundations of national security of Ukraine (2003). Available at: https://zakon.rada.gov.ua/laws/show/964-15\#Text

Schot, J., \& Steinmueller, W. E. (2018). Three frames for innovation policy: R\&D, systems of innovation and transformative change. Research Policy, 47(9), 1554-1567. Available at: https://www.sciencedirect.com/science/article/pii/S0048733318301987

The Commercial Code of Ukraine (2003). Available at: https://zakon.rada.gov.ua/laws/show/436-15?lang=en\#Text

Vasconcelos, V.V. (2021). Social justice and sustainable regional development: reflections on discourse and practice in public policies and public budget. Insights into Regional Development, 3(1), 10-28. https://doi.org/10.9770/IRD.2021.3.1(1) 


\section{ENTREPRENEURSHIP AND SUSTAINABILITY ISSUES}

ISSN 2345-0282 (online) http://jssidoi.org/jesi/

2021 Volume 8 Number 3 (March)

http://doi.org/10.9770/jesi.2021.8.3(22)

Make your research more visible, join the Twitter account of ENTREPRENEURSHIP AND SUSTAINABILITY ISSUES: @Entrepr69728810

Olha BEZPALOVA, Doctor of Jurisprudence, Professor, Kharkiv National University of Internal Affairs

ORCID ID: orcid.org/0000-0003-2886-695X

Maryna YUNINA, Candidate of Legal Sciences, Associate Professor, Dnipropetrovsk State University of Internal Affairs

ORCID ID: orcid.org/0000-0003-0311-4591

Svitlana KOROHOD, Lecturer, Dnipropetrovsk State University of Internal Affairs

ORCID ID: orcid.org/https://orcid.org/0000-0003-0210-1772

Kristina REZVOROVICH, $\mathrm{PhD}$ in Law, Dnipropetrovsk State University of Internal Affairs

ORCID ID: orcid.org/0000-0003-1183-613X

Tsahik OHANISIAN, Candidate of Law, Dnipropetrovsk State University of Internal Affairs

ORCID ID: orcid.org/0000-0001-9329-5378

Copyright (C) 2021 by author(s) and VsI Entrepreneurship and Sustainability Center

This work is licensed under the Creative Commons Attribution International License (CC BY).

http://creativecommons.org/licenses/by/4.0/

(c) (i) Open Access 